\title{
Evaluation of Activated Charcoal as an Alternative to Antimicrobials for the Treatment of Neonatal Calf Diarrhea
}

\author{
Joseph Ross (iD \\ Crystal Schatz' \\ Kendall Beaugrand' \\ Sjoert Zuidhof ${ }^{2}$ \\ Brenda Ralston ${ }^{3}$ \\ Nick Allan (iD) \\ Merle Olson (1D ${ }^{4}$ \\ 'Chinook Contract Research Inc., \\ Airdrie, AB, Canada; ${ }^{2}$ Sjoert Zuidhof \\ Consulting, Okotoks, $A B$, Canada; \\ ${ }^{3}$ Alberta Agriculture and Forestry, \\ Airdrie, AB, Canada; ${ }^{4}$ Alberta Veterinary \\ Laboratories Ltd., Calgary, AB, Canada
}

Correspondence: Joseph Ross Email joe.ross@ccr0I.com
Purpose: Neonatal calf diarrhea (NCD) is a major cause of death and economic loss in the cattle industry. Although NCD is caused by a variety of nutritional factors and non-bacterial pathogens, treatment typically includes systemic antimicrobial therapy, even for non-severe cases that are more likely to have non-bacterial causes. Novel, non-antimicrobial therapies are needed to reduce antimicrobial use and optimize production efficiency.

Methods: This production-level study compared the efficacy of activated charcoal to that of an antimicrobial regimen for treating mild-to-moderate cases of NCD, and identified the most common etiological agents. Calves diagnosed with non-severe diarrhea were randomly allocated into 3 treatment groups ( $\mathrm{n}=86$ per group): group A received a standard antimicrobial regimen, $\mathrm{B}$ received both antimicrobials and activated charcoal, and $\mathrm{C}$ received activated charcoal only. Animals were monitored over the course of 7 days for mortality and recovery from diarrhea. Fecal samples were collected upon enrollment (day 0) and on day 7 to assess the presence of major NCD-causing pathogens.

Results: Mortality was higher for groups B and C relative to A, although this difference was only statistically significant for group B vs A. No significant difference in the number of recovered animals was observed among the treatment groups, although group $\mathrm{C}$ was significantly slower to recover than A or B. The vast majority of day 0 samples were positive for non-bacterial organisms (mainly rotavirus and Cryptosporidium parvum), which decreased significantly by day 7 regardless of treatment group.

Conclusion: Antimicrobials only moderately improved outcomes for non-severe diarrhea cases relative to activated charcoal. Thus, systemic antimicrobial treatment is likely unnecessary for the majority of NCD cases and should be limited to severe cases.

Keywords: antimicrobial stewardship, activated charcoal, scours, non-bacterial, rotavirus, cryptosporidium

\section{Introduction}

Neonatal calf diarrhea (NCD) is a major cause of death and economic loss in the cattle industry. ${ }^{1}$ Diarrhea in calves is a multi-factorial disease that can be caused by nutritional factors and a variety of pathogens, including viruses (bovine rotavirus, bovine coronavirus, bovine viral diarrhea virus, bovine torovirus, bovine norovirus, nebovirus), bacteria (Escherichia coli, Clostridium perfringens, Salmonella spp.), and parasites (Cryptosporidium and Eimeria spp.). ${ }^{2,3}$ Some pathogens produce toxins (eg, enterotoxigenic E. coli, Salmonella spp., Clostridia spp.) and cause a secretory diarrhea, where water and electrolytes are secreted into the lumen of the small intestine, ${ }^{2}$ whereas others (eg, rotavirus, coronavirus, Cryptosporidium, 
Eimeria, and enteroinvasive E. coli and Salmonella spp.) infect the enterocytes of the intestines, causing villous atrophy and a maldigestive, malabsorptive diarrhea., ${ }^{2,4}$ Campylobacter spp. have also been associated with $\mathrm{NCD} .{ }^{5,6}$ Clinically, calves with NCD will produce large volumes of watery manure (with or without blood and fibrin) and display varying degrees of dehydration and acidosis, inappetence, depression, and in severe cases, septicemia. $^{7}$ Therapy typically involves treatment with fluids to correct hydration status and acid-base balance, anti-inflammatory therapy to improve comfort and reduce inflammation, and systemic antimicrobials. ${ }^{8}$

Given the multifactorial nature of NCD (bacterial, viral, protozoal, nutritional, etc.), there is a paucity of evidence for the effectiveness of routine antimicrobial use in non-severe diarrhea cases. ${ }^{8}$ Recent work has found that calves with mild or moderate diarrhea and no signs of systemic infection (eg, without fever and/or blood in their manure) do not require antimicrobial therapy, ${ }^{9}$ and that targeted therapy improves NCD recovery, feed intake, and weight gain relative to more conventional, antimicrobial-intensive husbandry. ${ }^{10}$ Moreover, aggressive treatment with antimicrobials may adversely affect the protective functions of the healthy gut microbiome by killing commensal bacteria. ${ }^{11}$ Given the current level of concern surrounding antimicrobial stewardship and resistance in food-producing animals, novel non-antimicrobial therapies are needed. Non-antimicrobial treatments for non-severe NCD could provide an effective tool to reduce antimicrobial use, minimize mortality, and optimize production efficiency. ${ }^{12}$

Activated charcoal is the product of thermal decomposition of organic plant materials. ${ }^{13}$ Activated charcoal can adsorb a variety of substances, including bacteria, toxins, and viruses. ${ }^{14}$ In vitro studies have found that activated charcoal can adsorb verotoxic E. coli, ${ }^{14}$ rotavirus, and coronavirus. ${ }^{15}$ Further, field studies have found that compounds containing activated charcoal may reduce the clinical signs associated with Cryptosporidium induced diarrhea in goats and cattle. ${ }^{16,17}$ Thus, activated charcoal might represent an effective alternative to antimicrobials for the treatment of mild to moderate NCD. The present study compares the efficacy of activated charcoal to that of a standard antimicrobial regimen for treating non-severe NCD and aims to identify the most common etiological agents associated with non-severe NCD. To best replicate real-world, industryrelevant conditions, this study was conducted at a typical commercial calf raising facility, thus producing productionlevel evidence for NCD management.

\section{Materials and Methods}

Overview and General Husbandry

This study was reviewed and approved by Chinook Contract Research's Institutional Animal Care and Use Committee (OLAW \#F19-00433, Application \#19042002). Animals were cared for in accordance with Canadian Council on Animal Care (CCAC) guidelines. ${ }^{18}$ The study was conducted at a typical commercial calf raising facility in southern Alberta, Canada. Calves were male Holstein or Holstein $\times$ Beef crosses, which were brought to the facility from multiple dairy farms in Alberta, British Columbia, and Manitoba. Upon arrival at the farm (at approximately 3-7 days of age), calves were placed into individual pens $(2.1 \times 0.76 \mathrm{~m})$ with a partially slatted floor. All animals were housed in multiple rooms of a barn with mechanical ventilation. Calves were vaccinated upon arrival with an 8-way clostridial vaccine (Tasvax 8, Merck Animal Health, Kirkland, QC, Canada) and an intranasal respiratory disease vaccine (Inforce 3, Zoetis Canada Inc., Kirkland, QC, Canada). Calves were fed milk replacer containing $30 \mathrm{mg} / \mathrm{kg}$ Decoquinate, $>24.0 \%(\mathrm{w} / \mathrm{w})$ crude protein, $>20.0 \%$ crude milk protein, $>17.0 \%$ crude fat, $<0.25 \%$ crude fiber, $0.95 \%$ calcium, $0.75 \%$ phosphorus, $0.55 \%$ sodium, $>44,000 \mathrm{IU} / \mathrm{kg}$ vitamin $\mathrm{A},>12,000 \mathrm{IU} / \mathrm{kg}$ vitamin $\mathrm{D},>275 \mathrm{IU} / \mathrm{kg}$ vitamin $\mathrm{E}$, and $0.3 \mathrm{mg} / \mathrm{kg}$ selenium (Functional Protein Blend + Deccox, Mapleview Agri Ltd., Drayton, ON, Canada). Milk replacer was diluted in water to $130 \mathrm{~g} / \mathrm{L}$ and fed twice daily (morning and afternoon). The total volume of milk replacers fed to neonatal calves upon arrival was $3 \mathrm{~L}$ per day; this was gradually increased to $6 \mathrm{~L}$ per day by the time they reached approximately 4 weeks of age. Calves were also fed, ad libitum, a dry textured custom feed containing $450 \mathrm{~g} /$ tonne chlortetracycline hydrochloride, $20 \mathrm{~g} /$ tonne of virginiamycin, and $33 \mathrm{~g} /$ tonne monensin (Trouw Nutrition, Lethbridge, Ab, Canada). Water was freely available via nipples.

\section{Study Enrollment and Treatment Regimen}

All animals were assessed daily by a facility technician for fecal consistency in the first 10 days following arrival. Specifically, each calf's feces were scored as follows: 0 = normal (feces hold its shape), $1=$ semi-formed or pasty, 2 $=$ loose (semi-formed pile, still stays on top of bedding), $3=$ 
watery diarrhea (mostly sifts through bedding; clear or yellow-hued liquid with some fecal matter). ${ }^{19}$ Diarrhea was defined as a fecal consistency score of $\geq 2$. If a calf presented with diarrhea in the first 10 days after arrival, a more thorough examination was completed, and a fecal sample was stored at $4{ }^{\circ} \mathrm{C}$ until analysis. As this study aimed to focus on mild-to-moderate cases of diarrhea, animals were excluded from the study if they presented with one or more of the following complicating conditions: pyrexia $\left(>39.5^{\circ} \mathrm{C}\right)$, blood/fibrin in the manure, clinical score of $>1$ in two of four categories assessed (in accordance with the WisconsinMadison Calf Health Scoring Chart), $>8 \%$ dehydration (assessed based on demeanor, eyeball recession, and skin tent duration), ${ }^{20}$ depression, or abnormal umbilicus (assessed by visual examination and manual palpation). Over the course of 14 months (from November 2019 to January 2021), animals were enrolled in the study sequentially (ie, continuously enrolled as they were diagnosed with diarrhea), and the date of enrollment was considered Day 0 . Upon enrollment in the study, the animals were randomly allocated to one of the three treatment groups (Table 1): (1) Treatment group A received a standard antimicrobial treatment (Cocci Scour Bolus, Alberta Veterinary Laboratories Ltd., Calgary, AB, Canada; 2 boluses administered orally per $50 \mathrm{~kg}$ of body weight twice daily the first day, and 1 bolus per
$50 \mathrm{~kg}$ of body weight twice daily for the following 2 consecutive days); (2) group B received both antimicrobials (as in A) and activated charcoal (Charcoal-Kaolin Oral Paste, Alberta Veterinary Laboratories Ltd., Calgary, AB, Canada; $30 \mathrm{~mL} / \mathrm{calf}$ administered orally, twice per day, for 2 days); and (3) group C received activated charcoal only (CharcoalKaolin Oral Paste, Alberta Veterinary Laboratories Ltd., Calgary, AB, Canada; $30 \mathrm{~mL} /$ calf administered orally, twice per day, for 2 days). Regardless of their assigned treatment group, all the animals in the study received a single dose of $5 \mathrm{~mL}$ of Meloxicam Oral Suspension (Alberta Veterinary Laboratories Ltd., Calgary, AB, Canada) upon a diarrhea diagnosis. Electrolyte therapy (Electrolyte Powder, Alberta Veterinary Laboratories Ltd., Calgary, AB, Canada) was given according to facility protocol, wherein animals received electrolytes on any day that they were assigned a dehydration score $\geq 2$, or if they have spent more than one day with a dehydration score $\geq 1$. Following enrollment, animals were monitored daily, and fecal consistency scores were assessed for 7 consecutive days. On the seventh day after enrollment (Day 7), a final fecal sample was collected. During the study, all researchers and staff were blinded to the treatment groups except the technician responsible for administering the treatments. A different technician was responsible for general health

Table I Treatment Groups and Dosing Regimen

\begin{tabular}{|c|c|c|c|c|}
\hline Group & Route & Dosage & Product $^{\mathbf{b}}$ & Active Ingredient(s) \\
\hline $\begin{array}{l}\text { A (Antimicrobials) } \\
n=86\end{array}$ & Oral & $\begin{array}{l}2 \text { boluses per } 50 \mathrm{~kg} \text { of body weight } \\
\text { twice daily the first day, and I bolus per } \\
50 \mathrm{~kg} \text { of body weight twice daily for } 2 \\
\text { days }\end{array}$ & Cocci Scour Bolus & $\begin{array}{l}250 \mathrm{mg} \text { neomycin, } 2000 \mathrm{mg} \text { sulfamethazine per } \\
\text { bolus }\end{array}$ \\
\hline $\begin{array}{l}\text { B (Antimicrobials }+ \\
\text { Charcoal) } n=86\end{array}$ & Oral & $\begin{array}{l}\text { Antimicrobials as above (A) } \\
\text { Charcoal as below (C) }\end{array}$ & $\begin{array}{l}\text { Cocci Scour Bolus } \\
\text { as above }(A) \text { and } \\
\text { Charcoal as below } \\
\text { (C) }\end{array}$ & \\
\hline$C($ Charcoal $) n=86$ & Oral & $\begin{array}{l}30 \mathrm{~mL} / \text { calf; twice per day (separated by } \\
2-4 \mathrm{hrs} \text { ) for } 2 \text { days }\end{array}$ & $\begin{array}{l}\text { Charcoal-Kaolin } \\
\text { Oral Paste }\end{array}$ & $\begin{array}{l}100 \text { mg Activated Charcoal, } 197 \text { mg Kaolin } \\
\text { per mL }\end{array}$ \\
\hline $\begin{array}{l}\text { Electrolytes } \\
n=104^{a}\end{array}$ & Oral & $\begin{array}{l}\text { I pouch in } 2 \mathrm{~L} \text {, repeat treatment twice } \\
\text { daily as necessary }\end{array}$ & $\begin{array}{l}\text { Electrolyte } \\
\text { powder }\end{array}$ & $\begin{array}{l}\text { Per } 76 \text { g pouch: } 41.734 \text { g dextrose, } 3.507 \\
\text { g sodium chloride, } 6.756 \text { g glycine, } 1.940 \\
\text { g potassium chloride, } 13.125 \text { g sodium acetate, } \\
0.6 \text { g sodium phosphate monobasic, } 0.349 \\
\text { g dipotassium phosphate, } 0.012 \text { g calcium } \\
\text { d-pantothenate }\end{array}$ \\
\hline $\begin{array}{l}\text { Meloxicam } n=258 \\
\text { (all animals) }\end{array}$ & $\begin{array}{l}\text { Oral } \\
\text { Drench }\end{array}$ & $5 \mathrm{~mL}$, once per calf & $\begin{array}{l}\text { Meloxicam Oral } \\
\text { Suspension }\end{array}$ & $15 \mathrm{mg} / \mathrm{mL}$ Meloxicam, USP \\
\hline
\end{tabular}

Notes: ${ }^{a}$ Electrolytes given to dehydrated calves according to facility protocols. ${ }^{\mathrm{b}}$ All products were obtained from Alberta Veterinary Laboratories Ltd. 
assessments, enrollment, recovery, and exit from the study. Individuals processing samples were also blinded to the treatment groups.

\section{Detection of Microorganisms}

To detect Rotavirus A, Betacoronavirus 1, Escherichia coli K99 (F5), and Cryptosporidium parvum, the Bovine Enterichek kit (Biovet Inc., Saint-Hyacinthe, QC, Canada) was used according to the manufacturer's instructions. Briefly, using the provided measuring spoon, a level spoonful of feces was removed from the sampling tube and mixed with the sterile Dilution Solution. Test strips were immersed in the diluted sample for up to ten minutes before reading the results ( + or -$)$. Additionally, the remaining sample (Dilution Solution plus feces) was serially diluted and plated onto two types of agar: Colorex Campylobacter Agar (Dalynn Biologicals, Calgary, AB, Canada) to enumerate Campylobacter species (yielding C. jejuni, C. coli, and C. lari as bright red colonies) or Chromocult Agar (Dalynn Biologicals, Calgary, AB, Canada) to enumerate total E. coli (yielding blue/violet colonies) and total coliforms (yielding pink/salmon red colonies). The campylobacter plates were incubated for 2-3 days at $41{ }^{\circ} \mathrm{C}$ under microaerobic conditions $\left(5 \% \mathrm{O}_{2}\right.$, $10 \% \mathrm{CO}_{2}, 85 \% \mathrm{~N}_{2}$ ). The Chromocult plates were incubated for $16-24$ hours at $37^{\circ} \mathrm{C}$ under standard aerobic conditions.

\section{Enumeration of Cryptosporidium Parvum Oocysts}

Oocysts were enriched from fecal samples and enumerated as previously described. ${ }^{21}$ Briefly, fecal samples were weighed, filtered, and washed with phosphate-buffered saline (PBS). The resulting filtrate was layered over 1 $\mathrm{M}$ sucrose (sp. gr. 1.13) and centrifuged at $800 \times \mathrm{g}$ for 5 min to concentrate oocysts at the sucrose layer surface. The upper filtrate layer and sucrose surface were pipetted into a clean tube and centrifuged again at $800 \times \mathrm{g}$ for 5 min. The resulting supernatant was decanted, and the pellet resuspended in $1 \mathrm{~mL}$ of PBS before spotting $0.015 \mathrm{~mL}$ onto a fluorescent microscope slide (Erie Scientific Co., Portsmouth, NH, USA). The slides were air dried in a biosafety cabinet before applying $0.02 \mathrm{~mL}$ of a Cryptosporidium-specific FITC-labeled monoclonal antibody solution (Crypt-a-glo, Waterborne, New Orleans, LA, USA). The slides were then placed in a moist container and incubated at $37^{\circ} \mathrm{C}$ for at least 1 hour before rinsing with PBS and air drying. Finally, slides were mounted with a fluorescent antibody mounting fluid (Aqua-polymount, Polysciences, Warrington, PA, USA) and a coverslip before enumerating oocysts at 400 $\mathrm{x}$ magnification with a dry objective on an epifluorescence microscope. The number of oocysts per gram of feces was calculated as follows:

$$
\mathrm{N}=\mathrm{s} /(\mathrm{V} \times \mathrm{m})
$$

Where $\mathrm{N}$ is the number of oocysts per gram of feces, $\mathrm{S}$ is the number of oocysts counted on the slide, $\mathrm{V}$ is the volume of sample examined $(0.015 \mathrm{~mL})$ and $\mathrm{m}$ is the mass of the fecal sample originally processed (in grams). The sensitivity of this detection method was 66 oocysts/g of feces.

\section{Statistical Analyses}

Mortality and time-to-recovery data were analyzed using Kaplan-Meier survival curves; overall P-values were calculated using a log-rank (Mantel-Cox) test. To account for multiple comparisons, P-values for pairwise comparisons were adjusted using the Holm-Š́́dák method and a familywise significance level of 0.05 . For all data with binary outcomes (ie, dead or alive, + or -), statistical significance was determined using Fisher's exact test and a significance level of $\mathrm{P}<0.05$. The experimental unit was defined as each individual animal. Statistical analyses were carried out in Prism v 9.1.2 (GraphPad Software, San Diego, CA, USA).

\section{Results}

\section{Effects of Antimicrobials versus Activated Charcoal on Mortality and Morbidity}

The overall mortality of the animals enrolled in this study was $6.2 \%$ over the course of the 7-day observation period (Table 2). Mortality was $1.2 \%, 9.3 \%$, and $8.1 \%$, respectively, for treatments $\mathrm{A}, \mathrm{B}$, and $\mathrm{C}$ (Table 2). No significant differences in mortality were observed for treatments $\mathrm{A}$ vs $\mathrm{C}(\mathrm{P}=$ $0.06)$ or $\mathrm{B}$ vs $\mathrm{C}(\mathrm{P}>0.99)$, although mortality was significantly higher for treatment $\mathrm{B}$ vs $\mathrm{A}(\mathrm{P}=0.03)$ (Table 2). Kaplan-Meier analysis indicated no significant differences in survival time for A vs $\mathrm{C}$ or $\mathrm{B}$ vs $\mathrm{C}$, although group $\mathrm{B}$ had a shorter survival time than $\mathrm{A}(\mathrm{P}=0.05)$ (Figure 1A). The majority of animals $(91.5 \%)$ recovered over the 7 -day observation period (ie, their fecal score returned to 0 or 1 ), with no significant differences among the treatments (Table 3). The mean time-to-recovery (ie, time to reach a fecal score of 1 or 0 ) was 2.27 days (standard deviation $=1.3$; range $=1$ to 7 days) (Table 3). Kaplan-Meier analysis indicated a median 
Table 2 Mortality of Animals Treated with Antimicrobials (A), Charcoal (C), or Both (B)

\begin{tabular}{|l|l|l|}
\hline Treatment & $\begin{array}{l}\text { Number of } \\
\text { Animals }\end{array}$ & $\begin{array}{l}\text { Number of Deceased } \\
\text { Animals (Percent) }\end{array}$ \\
\hline A & 86 & $1(1.16 \%)^{\mathrm{a}}$ \\
\hline B & 86 & $8(9.30 \%)^{\mathrm{a}}$ \\
\hline C & 86 & $7(8.14 \%)$ \\
\hline Total & 258 & $16(6.20 \%)$ \\
\hline
\end{tabular}

Notes: ${ }^{\mathrm{A} A}$ vs $\mathrm{B}: \mathrm{P}=0.03$; $\mathrm{B}$ vs $\mathrm{C}: \mathrm{P}>0.99$; $\mathrm{A}$ vs $\mathrm{C}: \mathrm{P}=0.06$; A vs Total: $\mathrm{P}=0.08$; $\mathrm{B}$ vs Total: $P=0.33 ; C$ vs Total: $P=0.62$. $P$ values were Calculated using Fisher's Exact Test.

time-to-recovery of 2, 2, and 3 days for groups A, B, and C, respectively, with group $\mathrm{C}$ being significantly slower to recover than $\mathrm{A}$ or $\mathrm{B}(\mathrm{P}<0.01$ and $\mathrm{P}=0.02$, respectively $)$ (Figure 1B).

\section{Etiology of Non-Severe Neonatal Calf Diarrhea}

According to the Enterichek kit, the vast majority of positive samples were non-bacterial: $61.9 \%, 1.9 \%$, and
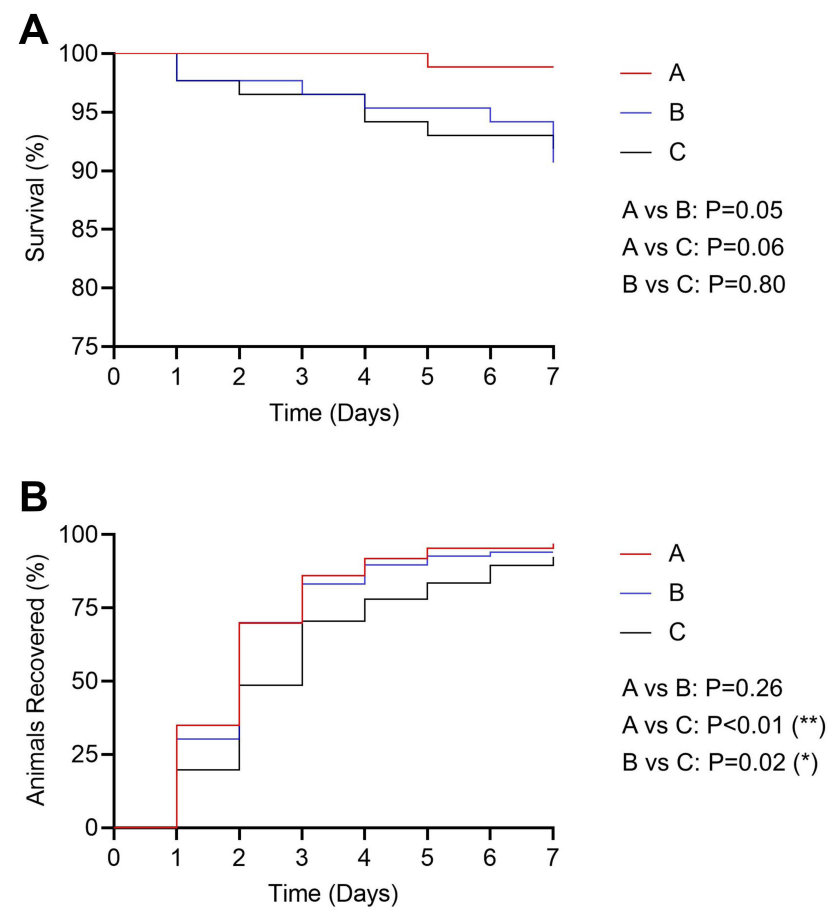

Figure I Kaplan-Meier curves of survival (A) or recovery (B) for animals treated with antimicrobials, charcoal, or antimicrobials + charcoal. $A=$ antimicrobials $(n=86)$; $C=$ charcoal $(n=86)$; $B=$ both $(n=86)$. For panel $B$, animals were censored when they died, as were animals that failed to recover over the 7-day period. Overall P-values were 0.0594 and 0.0063 for panels $A$ and $B$, respectively (calculated using a Log rank test). The indicated $P$-values ( $A$ vs $B, A$ vs $C$, and $B$ vs $C$ ) were adjusted for multiple comparisons using the Holm-Šídák method and a family-wise significance level of 0.05 . $* \mathrm{P}<0.05 ; * * \mathrm{P}<0.01$.
Table 3 Recovery of Animals Treated with Antimicrobials (A), Charcoal (C), or Both (B)

\begin{tabular}{|l|l|l|}
\hline Treatment & $\begin{array}{l}\text { Number of } \\
\text { Animals }\end{array}$ & $\begin{array}{l}\text { Number of Recovered } \\
\text { Animals (Percent) }\end{array}$ \\
\hline A & 86 & $83(96.5 \%)$ \\
\hline B & 86 & $78(90.7 \%)$ \\
\hline C & 86 & $75(87.2 \%)$ \\
\hline Total & 258 & $236(91.5 \%)$ \\
\hline
\end{tabular}

Notes: A vs $B: P=0.21$; $B$ vs $C: P>0.99 ; A$ vs $C: P=0.13$; A vs Total: $P=0.22 ; B$ vs Total: $P=0.65 ; C$ vs Total: $P=0.50$. $P$ values were Calculated using Fisher's Exact Test.

$77.0 \%$ of the animals were positive for rotavirus, coronavirus, and C. parvum, respectively, while just $0.8 \%$ of the animals were positive for E. coli K99 (F5) (Table 4). Notably, $45.1 \%$ were positive for both rotavirus and C. parvum, and only $5.1 \%$ were negative for all four organisms. The recovery rate for Campylobacter spp. by direct culture was also low (1.6\% of animals, with an average recovery of approximately $10^{4} \mathrm{CFU} / \mathrm{mL}$ in the positive samples), although total E. coli and coliforms were recovered at rates of $99.6 \%$ and $92.2 \%$, respectively, with average recoveries of approximately $10^{5} \mathrm{CFU} / \mathrm{mL}$ (Table 4). The performance of the Enterichek C. parvum strips was confirmed by comparing its results to a count of C. parvum oocysts, which yielded $10.5 \%$ false negatives and $0.8 \%$ false positives; the mean oocyst count for the false negatives was 1045 oocysts/g feces, suggesting a lower limit of detection in this range (Table 4 and Supplemental Table S1). Overall, the diagnostic performance of the Enterichek kit, at least for C. parvum detection, was deemed acceptable for the purposes of this study.

\section{Effects of Antimicrobials versus Activated Charcoal on Microbial Burden}

Within each of the treatment groups (A, B, or C), significant reductions were observed in the positivity rate for rotavirus (Table 5) and C. parvum (Table 6) by Day 7, relative to Day 0. The initial numbers for E. coli K99 (F5) (Table 7) and coronavirus (Table 8) were too low to demonstrate significant decreases by Day 7, although both dropped to zero over this period. No significant differences in pathogen load were observed amongst the various treatment groups (ie, A vs B, A vs $\mathrm{C}$, or B vs C) at Day 0, indicating a similar overall diagnosis rate of the various pathogens among the treatment groups (Tables 5-8). By day 7, rotavirus was significantly lower in group $A$ relative to $B(P=0.03)$ (Table 5), with no 
Table 4 Pathogens Detected in Fecal Samples from Diarrhetic Calves

\begin{tabular}{|c|c|c|c|c|}
\hline Method of Detection & Organism & $\begin{array}{l}\text { Mean } \log _{10} \text { CFU/mL or Oocysts/g Feces } \\
\pm \text { SD }\end{array}$ & $\begin{array}{l}\text { Number of Positive } \\
\text { Animals }^{\mathrm{a}}\end{array}$ & $\begin{array}{l}\text { Positivity Rate } \\
\text { (\%) }\end{array}$ \\
\hline \multirow[t]{5}{*}{ Enterichek } & Rotavirus & \multirow[t]{5}{*}{$N / A$} & 159 & 61.9 \\
\hline & Coronavirus & & 5 & 1.95 \\
\hline & E. coli K99 (F5) & & 2 & 0.778 \\
\hline & C. parvum & & 198 & 77.0 \\
\hline & $\begin{array}{l}\text { Rotavirus + } \\
\text { C. parvum }\end{array}$ & & 116 & 45.1 \\
\hline \multirow{3}{*}{$\begin{array}{l}\text { Plating on chromogenic } \\
\text { agar }\end{array}$} & Campylobacter spp. & $4.25 \pm 0.83^{\mathrm{b}}$ & 4 & 1.56 \\
\hline & Total E. coli & $5.90 \pm 1.23$ & 256 & 99.6 \\
\hline & Total coliforms & $4.99 \pm 1.86$ & 237 & 92.2 \\
\hline Fluorescence microscopy & C. parvum oocysts ${ }^{\mathrm{c}}$ & $3.40 \pm 1.47$ & 223 & 86.8 \\
\hline
\end{tabular}

Notes: ${ }^{\mathrm{a}}$ The total number of animals sampled was 257 . ${ }^{\mathrm{b}}$ Only calculated for the 4 positive samples. ${ }^{\mathrm{c}} 2 / 257$ ( $0.78 \%$ ) of samples yielded false positives (ie, Enterichek was positive but the oocyst count was 0); $27 / 257$ (10.5\%) of samples yielded false negatives (ie, Enterichek was negative but oocysts were counted).

Abbreviations: SD, standard deviation; N/A, not applicable.

Table 5 Enterichek Positivity Rate for Rotavirus at Days 0 and 7, Organized by Treatment Group

\begin{tabular}{|l|l|l|l|l|}
\hline \multirow{2}{*}{ Treatment } & \multirow{2}{*}{$\begin{array}{l}\text { Number of } \\
\text { Samples }\end{array}$} & \multicolumn{2}{|l|}{$\begin{array}{l}\text { Number of Positive } \\
\text { Samples (Percent) }\end{array}$} & \multirow{2}{*}{$\begin{array}{l}\text { P (Day } \\
\text { 0 vs 7) }\end{array}$} \\
\cline { 3 - 4 } & & Day 0 & Day 7 & \\
\hline A & 85 & $54(63.5 \%)$ & $I(I .2 \%)^{\mathrm{b}}$ & $<0.000 \mathrm{I}$ \\
\hline $\mathrm{B}$ & 80 & $45(56.3 \%)$ & $7(8.8 \%)^{\mathrm{b}}$ & $<0.000 \mathrm{I}$ \\
\hline C & 78 & $49(62.8 \%)$ & $2(2.6 \%)$ & $<0.000 \mathrm{I}$ \\
\hline Total & 243 & $148(60.9 \%)$ & $10(4.1 \%)$ & $<0.000 \mathrm{I}$ \\
\hline
\end{tabular}

Notes: a Calculated using Fisher's Exact Test. ${ }^{b}$ For $A$ vs $B$ on Day $7, P=0.03$. For all other pairwise comparisons, $\mathrm{P} \geq 0.17$.

Table 6 Enterichek Positivity Rate for C. parvum at Days 0 and 7, Organized by Treatment Group

\begin{tabular}{|c|c|c|c|c|}
\hline \multirow[t]{2}{*}{ Treatment } & \multirow{2}{*}{$\begin{array}{l}\text { Number } \\
\text { of } \\
\text { Samples }\end{array}$} & \multicolumn{2}{|c|}{$\begin{array}{l}\text { Number of Positive } \\
\text { Samples (Percent) }\end{array}$} & \multirow[t]{2}{*}{$\begin{array}{l}P(\text { Day } \\
0 \text { vs } 7)^{a}\end{array}$} \\
\hline & & Day 0 & Day 7 & \\
\hline A & 85 & 70 (82.4\%) & 33 (38.8\%) & $<0.0001$ \\
\hline B & 80 & 66 (82.5\%) & 37 (46.3\%) & $<0.0001$ \\
\hline C & 78 & $54(69.2 \%)$ & $39(50.0 \%)$ & 0.0220 \\
\hline Total & 243 & 190 (78.2\%) & 109 (44.9\%) & $<0.0001$ \\
\hline
\end{tabular}

Notes: ${ }^{\mathrm{a} C a l c u l a t e d}$ using Fisher's Exact Test. For $\mathrm{B}$ vs $\mathrm{C}$ on Day $0, \mathrm{P}=0.06$; for $\mathrm{A}$ vs $\mathrm{C}$ on Day 0, $P=0.07$; for $A$ vs $C$ on Day 7, $P=0.16$; for all other pairwise comparisons, $P \geq 0.35$.

other significant differences in pathogen load amongst the various treatment groups observed (Tables 5-8). Overall, these results indicate that the shedding of pathogens in calf
Table 7 Enterichek Positivity Rate for E. coli K99 (F5) at Days 0 and 7, Organized by Treatment Group

\begin{tabular}{|c|c|c|c|c|}
\hline \multirow[t]{2}{*}{ Treatment } & \multirow[t]{2}{*}{$\begin{array}{l}\text { Number of } \\
\text { Samples }\end{array}$} & \multicolumn{2}{|c|}{$\begin{array}{l}\text { Number of } \\
\text { Positive } \\
\text { Samples } \\
\text { (Percent) }\end{array}$} & \multirow[t]{2}{*}{$\begin{array}{l}\text { P (Day } 0 \\
\text { vs } 7)^{a}\end{array}$} \\
\hline & & Day 0 & Day 7 & \\
\hline A & 85 & 0 & 0 & $>0.9999$ \\
\hline B & 80 & $2(2.5 \%)$ & 0 & 0.4969 \\
\hline C & 78 & 0 & 0 & $>0.9999$ \\
\hline Total & 243 & $2(0.8 \%)$ & 0 & 0.4990 \\
\hline
\end{tabular}

Notes: a Calculated using Fisher's Exact Test. For A vs B on Day $0, \mathrm{P}=0.23$; for all other pairwise comparisons, $P \geq 0.50$.

Table 8 Enterichek Positivity Rate for Coronavirus at Days 0 and 7, Organized by Treatment Group

\begin{tabular}{|l|l|l|l|l|}
\hline Treatment & $\begin{array}{l}\text { Number of } \\
\text { Samples }\end{array}$ & \multicolumn{2}{|l|}{$\begin{array}{l}\text { Number of } \\
\text { Positive } \\
\text { Samples } \\
\text { (Percent) }\end{array}$} & P (Day 0 \\
vs 7)
\end{tabular}

Notes: ${ }^{a}$ Calculated using Fisher's Exact Test. For $B$ vs $C$ on Day $0, P=0.12$; for all other pairwise comparisons, $\mathrm{P} \geq 0.35$. 
feces decreased significantly in the first 7 days following the diagnosis of diarrhea, regardless of which treatment regimen was applied.

\section{Discussion}

As of December 1, 2018, Health Canada regulations stipulate that all Medically Important Antimicrobials (MIAs) for veterinary use are sold by prescription only. ${ }^{22,23}$ As part of the stewardship pillar for the national framework for the responsible use of antimicrobials, the Canadian Veterinary Medicine Association aims to conserve the effectiveness of antimicrobials by ensuring good antimicrobial stewardship. ${ }^{24}$ Antimicrobial stewardship includes those set of practices that ensure that MIAs are used in a responsible manner to preserve their efficacy. An important aspect of stewardship is replacement-finding efficacious nonantimicrobials alternative products that fight infectious disease and reduce the need to use antimicrobials. The present study sets out to evaluate the efficacy of activated charcoal as an alternative treatment to standard antimicrobials for the treatment of non-severe neonatal diarrhea, as well as to investigate the most common etiological agents. To best replicate real-world, industry-relevant conditions, this study was conducted at a typical commercial calf-raising facility in Southern Alberta, Canada. The results herein are potentially complicated by the lack of a control group that received no antimicrobials or activated charcoal. Such a control was deemed impractical and unethical, as neither the animal care and use committee nor the producer would consent to denying treatment to animals diagnosed with NCD. Similarly, meloxicam had to be given to all animals to address abdominal pain and inflammation. Instead, this study focused on comparing the efficacy of the proposed alternative treatment to that of the standard-of-care treatment used in this industry, ie, systemic antimicrobials.

To better understand the etiology of non-severe diarrhea in calves, this study determined which of a specific group of microorganisms were present at detectable levels in Day 0 fecal samples (ie, upon diagnosis of diarrhea). The chosen organisms represent the pathogens known to most commonly cause NCD, including bovine rotavirus A, bovine coronavirus, enterotoxigenic E. coli $\mathrm{K} 99$ (F5), and C. parvum (reviewed in). ${ }^{2,3}$ The four major bovine enteropathogens were detected using a commercially available "dipstick" test (Bovine Enterichek), which is based on an antigencapture enzyme-linked immunosorbent assay (ELISA). This kit is marketed as a rapid pen-side test that can be performed in the field. The manufacturer states the diagnostic sensitivity to be $96.0 \%, 63.6 \%, 82.6 \%$, and $78.3 \%$ for rotavirus, coronavirus, E. coli $\mathrm{K} 99$ (F5), and C. parvum, respectively; the manufacturer states the specificity to be $100.0 \%$, 97.4\%, 94.4\%, and 93.3\% for the same organisms (Biovet Inc. Technical Support, personal communication). Notably, the manufacturer assessed sensitivity and specificity against polyacrylamide gel electrophoresis with silver staining (for rotavirus), real-time (RT) PCR (for coronavirus), and conventional PCR (for E. coli K99 (F5) and C. parvum). An independent verification of the kit's diagnostic performance, relative to a multiplex RT-PCR assay, concluded the sensitivity to be $42.3 \%, 60.0 \%, 71.4 \%$, and $81.5 \%$, and the specificity to be $100.0 \%, 51.4 \%, 100.0 \%$, and $98.6 \%$ for rotavirus, coronavirus, E. coli K99 (F5), and C. parvum, respectively. ${ }^{25}$ In the present study, the diagnostic performance of the kit for detecting $C$. parvum was compared to a quantitation of C. parvum oocysts by immunofluorescence microscopy, indicating a false negative and false positive rate of $10.5 \%$ and $0.78 \%$, respectively (indicating a sensitivity of $89.5 \%$ and specificity of $99.2 \%$ ). A caveat here is that oocysts only represent one life stage for this organism. ${ }^{26}$ The mean oocyst count for the false negatives in the present study was 1045 oocysts/g feces, suggesting a lower limit of detection in this range. For comparison, one study reports the median infectious dose $\left(\mathrm{ID}_{50}\right)$ in dairy calves experimentally challenged with $C$. parvum oocysts is 6 to cause fecal oocyst shedding, 10 to cause diarrhea, and 17 to cause fecal oocyst shedding with diarrhea; ${ }^{27}$ however, the number required to cause identifiable disease characteristics would likely vary greatly between individual animals. ${ }^{26}$ The current study identified $61.9 \%, 1.9 \%$, and $77.0 \%$ of calves with non-severe diarrhea as positive for rotavirus $\mathrm{A}$, coronavirus, and $C$. parvum, respectively. A recent study that sent frozen fecal samples to a commercial laboratory for RT-PCR analysis reports positivity rates of $94.2 \%, 85.8 \%$, and $57.4 \%$ for rotavirus A, coronavirus, and C. parvum, respectively. ${ }^{28}$ It is unclear why the coronavirus prevalence was so much lower in the current study, although it could be partially explained by a lower sensitivity of the Enterichek assay used here relative to the RT-PCR assay employed in the former. It is also possible that coronavirus prevalence was simply lower in the animals used in the present study.

Only $0.8 \%$ of Day 0 samples were positive for E. coli K99 (F5). As Campylobacter spp. have also been associated with $\mathrm{NCD},{ }^{5,6}$ the present study sought to further explore this association by directly plating onto chromogenic agar to evaluate the presence of common Campylobacter species. As noted for 
E. coli K99 (F5), the prevalence of Campylobacter spp. was also quite low, with only $1.6 \%$ of samples yielding colonies. For comparison, a Campylobacter spp. positivity rate of $4.4 \%$ has been reported for a similar direct-plating method. ${ }^{29}$ Unsurprisingly, that $4.4 \%$ positivity rate increased to $37.4 \%$ when the samples were first enriched in a Campylobacterpromoting growth medium prior to plating, ${ }^{29}$ suggesting that direct plating will lead to a systematically low positivity rate. However, direct plating allows for an accurate quantitation of Campylobacter colony forming units, as was employed in the present study, yielding an average recovery of approximately $10^{4} \mathrm{CFU} / \mathrm{mL}$ for those samples that were positive for Campylobacter spp. The generally low positivity rates of E. coli K99 (F5) and Campylobacter spp. reported herein could possibly be explained by the fact that all animals enrolled in this study received an in-feed antimicrobial regimen, which is still commonly practiced in Canada. However, total E. coli and coliforms - which were used in this study as a measure of total bacterial loads-were recovered at rates of $99.6 \%$ and $92.2 \%$, respectively, with average recoveries of approximately $10^{5}$ to $10^{6} \mathrm{CFU} / \mathrm{mL}$ (after diluting roughly $1 \mathrm{~g}$ of fecal sample in roughly $2 \mathrm{~mL}$ of Enterichek dilution buffer). For reference, a study of enteric bacteria in fresh bovine feces from grazing animals reports numbers of approximately $10^{6} \mathrm{CFU} / \mathrm{g}$ wet weight for $E$. coli and $10^{5} \mathrm{CFU} / \mathrm{g}$ wet weight for Campylobacter. ${ }^{30}$ It is thus unlikely that in-feed antibiotics led to a severe reduction of total bacterial loads in the present study. Another possible explanation for the low recovery rate of $E$. coli K99 could be the age of the animals in this study: while $E$. coli can enter intestinal epithelial cells within hours of calving, ${ }^{31,32}$ the calves studied here were 3-7 days old. In any case, it would be interesting to replicate this study in a jurisdiction where in-feed antimicrobial use is not practiced.

NCD is the most common cause of death in dairy calves under 30 days of age, with a case-fatality rate of approximately $5 \% .{ }^{33-35}$ Overall mortality of the animals enrolled in the present study was $6.2 \%$ over the course of the 7-day observation period, which was considered typical for this facility. Importantly, the animals on this study were managed according to the existing facility practices. Overall, $91.5 \%$ of the animals recovered over the same period. It is worth noting that the sources of the calves at this commercial operation were known and the transfer of passive immunity (TPI) status from each calf supplier was established as a condition of sale. We nonetheless tested a subset of animals prior to initiating the present study, confirming that most animals $(83.4 \%)$ had at least a fair TPI status, while $16.6 \%$ were considered poor (Table S2).
While it would be ideal for the facility to test for TPI for all incoming animals, this would be impractical due to labor constraints. It is tempting to speculate that improved nutrition and colostrum management would have a more profound impact on overall animal health-including the prevention of NCD - than intervention with antimicrobials. It is also worth noting that all of the animals enrolled in the present study were given a non-steroidal antiinflammatory (meloxicam) upon diagnosis of NCD, which is not approved for use in cattle in some jurisdictions. It is certainly possible that this anti-inflammatory treatment influenced overall recovery rates, suggesting that the results presented here might change if the study were repeated in the absence of meloxicam.

Fewer animals died in the antimicrobial-treated group (A) than in the charcoal-treated (C) or dual-treated (B) group, although only the B vs A comparison met the threshold for statistical significance, raising the possibility that activated charcoal in addition to antimicrobials is detrimental. For instance, there could be an interaction between activated charcoal and the antimicrobials administered orally. However, this is not supported by the recovery data, as no significant difference in percent recovery was observed between groups A, B, and $\mathrm{C}$, although the charcoal-treated group was significantly slower to recover than the antimicrobial-treated or dual-treated animals. Taken together, these results suggest that antimicrobials lead to, at best, a moderate improvement in outcomes for calves with non-severe diarrhea relative to the calves treated with activated charcoal or the dual treatment. This raises an important question: is the slight improvement worth the added financial expense of indiscriminate antimicrobial treatment, as well as its detrimental effects on the cattle industry's social license? The utility of treating non-severe NCD — which is less likely to have a bacterial cause - with antimicrobials is particularly questionable when the animals already receive in-feed antimicrobials. For instance, targeted antimicrobial therapy in herds managed without in-feed antimicrobials has been shown to improve NCD recovery, feed intake, and weight gain relative to more conventional, antimicrobial-intensive husbandry. ${ }^{10}$ Given that most day 0 fecal samples were positive for nonbacterial pathogens, and that other studies have suggested little or no benefit to using antimicrobials in mild-to-moderate cases of $\mathrm{NCD},{ }^{8,9}$ it is unlikely that antimicrobials will improve outcomes for the majority of NCD cases. Indeed, regardless of treatment, most animals in the present study recovered - and the microbial burden decreased significantly — by day 7 . These data suggest that a strong immune response is more effective than treatment with either antimicrobials or charcoal, which 
likely warrants a large-scale clinical study to evaluate the efficacy of calfhood vaccination to protect calves from rotaviral and coronaviral diarrhea. Vaccination of the dam is a good practice, but it may fail to protect the calves when colostrum is not provided in adequate amounts. ${ }^{36-39}$

\section{Conclusion}

The majority of non-severe NCD cases are likely caused by non-bacterial organisms (mainly rotavirus and C. parvum); accordingly, antimicrobials only moderately improved outcomes for calves with non-severe NCD relative to activated charcoal. Systemic antimicrobial treatment is likely unnecessary for the majority of non-severe cases of NCD and should be limited to severe cases, which are more likely to have a bacterial cause.

\section{Abbreviation}

NCD, neonatal calf diarrhea.

\section{Ethics Approval}

The present field-based study was conducted in compliance with the best practice of veterinary care in accordance with the research guidelines set forth by the Canadian Council on Animal Care and was approved by the Institutional Animal Care and Use Committee of Chinook Contract Research Inc. (Airdrie, Alberta, Canada).

\section{Consent}

The owners provided informed consent for their animals to be used in the present study.

\section{Acknowledgments}

The authors wish to acknowledge the producer and the farm staff responsible for health assessments and treatment administration, as well as the technicians, the researchers, and the animals that contributed to this study. We also thank S. Roche at ACER Consulting for valuable feedback on the manuscript. The funding was provided by both the Alberta and Canadian Governments through the Canadian Agricultural Partnership (CAP) Accelerating the Advancement of Agricultural Innovation Program. Finally, we thank J. Flaig and K. Macmillan of Alberta Milk for administration of the CAP funding and provision of valuable intellectual input.

\section{Author Contributions}

All authors made substantial contributions to conception and design, acquisition of data, or analysis and interpretation of data; took part in drafting the article or revising it critically for important intellectual content; agreed to submit to the current journal; gave final approval for the version to be published; and agreed to be accountable for all aspects of the work.

\section{Funding}

The funding was provided by both the Alberta and Canadian Governments through the Canadian Agricultural Partnership (CAP) Accelerating the Advancement of Agricultural Innovation Program.

\section{Disclosure}

$\mathrm{SZ}$ provides consulting services to AVL/Solvet and MO receives salary from AVL/Solvet, which markets the electrolytes, meloxicam, antimicrobials, and activated charcoal used in this study. Dr Joseph Ross reports grants from Government of Alberta, grants from Government of Canada, during the conduct of the study; non-financial support from Alberta Veterinary Laboratories Ltd., outside the submitted work. Dr Brenda Ralston reports grants from Canadian Agricultural Partnership, non-financial support from Alberta Veterinary Laboratories, during the conduct of the study; non-financial support from Alberta Veterinary Laboratories, outside the submitted work.

Mr Nick Allan reports grants from Alberta Milk, during the conduct of the study; non-financial support from Alberta Veterinary Laboratories, outside the submitted work.

The authors report no other conflicts of interest in this work.

\section{References}

1. Donovan GA, Dohoo IR, Montgomery DM, Bennett FL. Associations between passive immunity and morbidity and mortality in dairy heifers in Florida, USA. Prev Vet Med. 1998;34(1):31-46. doi:10.1016/s01675877(97)00060-3

2. Foster DM, Smith GW. Pathophysiology of diarrhea in calves. Vet Clin North Am Food Anim Pract. 2009;25(1):13-36,xi. doi:10.1016/j. cvfa.2008.10.013

3. Cho YI, Yoon KJ. An overview of calf diarrhea - infectious etiology, diagnosis, and intervention. J Vet Sci. 2014;15(1):1-17. doi:10.4142/ jvs.2014.15.1.1

4. Buret AG. Pathophysiology of enteric infections with Giardia duodenalius. Parasite. 2008;15(3):261-265. doi:10.1051/parasite/2008153261

5. Klein D, Alispahic M, Sofka D, Iwersen M, Drillich M, Hilbert F. Prevalence and risk factors for shedding of thermophilic Campylobacter in calves with and without diarrhea in Austrian dairy herds. J Dairy Sci. 2013;96(2):1203-1210. doi:10.3168/jds.2012-5987

6. Schulze F. Campylobacter als Diarrhoeerreger beim Kalb [Campylobacter as the cause of diarrhea in calves]. Dtsch Tierarztl Wochenschr. 1992;99(11):458-461. German.

7. Smith GW, Berchtold J. Fluid therapy in calves. Vet Clin North Am Food Anim Pract. 2014;30(2):409-27, vi. doi:10.1016/j. cvfa.2014.04.002 
8. Constable PD. Treatment of calf diarrhea: antimicrobial and ancillary treatments. Vet Clin North Am Food Anim Pract. 2009;25(1):101-20, vi. doi:10.1016/j.cvfa.2008.10.012

9. Gomez DE, Arroyo LG, Poljak Z, Viel L, Weese JS. Implementation of an algorithm for selection of antimicrobial therapy for diarrhoeic calves: impact on antimicrobial treatment rates, health and faecal microbiota. Vet J. 2017;226:15-25. doi:10.1016/j.tvj1.2017.06.009

10. Berge AC, Moore DA, Besser TE, Sischo WM. Targeting therapy to minimize antimicrobial use in preweaned calves: effects on health, growth, and treatment costs. J Dairy Sci. 2009;92(9):4707-4714. doi:10.3168/jds.2009-2199

11. Schokker D, Zhang J, Vastenhouw SA, et al. Long-lasting effects of early-life antibiotic treatment and routine animal handling on gut microbiota composition and immune system in pigs. PLoS One. 2015;10(2):e0116523. doi:10.1371/journal.pone.0116523

12. Marquardt RR, Li S. Antimicrobial resistance in livestock: advances and alternatives to antibiotics. Anim Front. 2018;8(2):30-37. doi:10.1093/af/vfy001

13. Toth JD, Dou Z. Use and impact of biochar and charcoal in animal production systems. In: Guo M, He Z, Uchimiya SM, editors. Agricultural and Environmental Applications of Biochar: Advances and Barriers. Soil Science Society of America, Inc. (SSSA); 2016:199-224.

14. Naka K, Watarai S, Tana T, et al. Adsorption effect of activated charcoal on enterohemorrhagic Escherichia coli. J Vet Med Sci. 2001;63(3):281-285. doi:10.1292/jvms.63.281

15. Clark KJ, Sarr AB, Grant PG, Phillips TD, Woode GN. In vitro studies on the use of clay, clay minerals and charcoal to adsorb bovine rotavirus and bovine coronavirus. Vet Microbiol. 1998;63(24):137-146. doi:10.1016/s0378-1135(98)00241-7

16. Paraud C, Pors I, Journal JP, Besnier P, Reisdorffer L, Chartier C. Control of cryptosporidiosis in neonatal goat kids: efficacy of a product containing activated charcoal and wood vinegar liquid (Obionekk $^{\circledR}$ ) in field conditions. Vet Parasitol. 2011;180(34):354-357. doi:10.1016/j.vetpar.2011.03.022

17. Watarai S, Tana KM. Feeding activated charcoal from bark containing wood vinegar liquid (nekka-rich) is effective as treatment for cryptosporidiosis in calves. J Dairy Sci. 2008;91(4):1458-1463. doi:10.3168/jds.2007-0406

18. Tennessen T, Connor L, Passillé A, et al. CCAC Guidelines On: The Care and Use of Farm Animals in Research, Teaching and Testing. Canadian Council on Animal Care; 2009.

19. Renaud DL, Buss L, Wilms JN, Steele MA. Technical note: is fecal consistency scoring an accurate measure of fecal dry matter in dairy calves? J Dairy Sci. 2020;103(11):10709-10714. doi:10.3168/ jds.2020-18907

20. Smith GW. Treatment of calf diarrhea: oral fluid therapy. Vet Clin North Am Food Anim Pract. 2009;25(1):55-72,vi. doi:10.1016/j. cvfa.2008.10.006

21. Ralston BJ, McAllister TA, Olson ME. Prevalence and infection pattern of naturally acquired giardiasis and cryptosporidiosis in range beef calves and their dams. Vet Parasitol. 2003;114 (2):113-122. doi:10.1016/s0304-4017(03)00134-1

22. Shock DA Medically important antibiotics require a prescription; 2019. Available from: https://www.amstewardship.ca/wp-content /uploads/2018/08/producer_EN_faastsheet_06.pdf. Accessed August $19,2019$.

23. Government of Canada. Responsible Use of Medically Important Antimicrobials in Animals. Government of Canada; 2018. Available from: https://www.canada.ca/en/public-health/services/antibioticantimicrobial-resistance/animals/actions/responsible-useantimicrobials.html. Accessed December 9, 2021.
24. CVMA. Veterinary Oversight of Antimicrobial Use - A PanCanadian Framework of Professional Standards for Veterinarians. Canadian Veterinary Medical Association. Available from: https:// www.canadianveterinarians.net/documents/pan-canadian-framework. Accessed December 9, 2021.

25. Cho YI, Sun D, Cooper V, Dewell G, Schwartz K, Yoon KJ. Evaluation of a commercial rapid test kit for detecting bovine enteric pathogens in feces. $J$ Vet Diagn Invest. 2012;24(3):559-562. doi:10.1177/1040638712440997

26. Bouzid M, Hunter PR, Chalmers RM, Tyler KM. Cryptosporidium pathogenicity and virulence. Clin Microbiol Rev. 2013;26 (1):115-134. doi:10.1128/cmr.00076-12

27. Zambriski JA, Nydam DV, Wilcox ZJ, Bowman DD, Mohammed HO, Liotta JL. Cryptosporidium parvum: determination of $\mathrm{ID}_{5 \mathrm{o}}$ and the dose-response relationship in experimentally challenged dairy calves. Vet Parasitol. 2013;197(1-2):104-112. doi:10.1016/j.vetpar.2013.04.022

28. Renaud DL, Rot C, Marshall J, Steele MA. The effect of Cryptosporidiumparvum, rotavirus, and coronavirus infection on the health and performance of male dairy calves. J Dairy Sci. 2021;104 (2):2151-2163. doi:10.3168/jds.2020-19215

29. Hakkinen M, Heiska H, Hänninen ML. Prevalence of Campylobacter spp. in cattle in Finland and antimicrobial susceptibilities of bovine Campylobacter jejuni strains. Appl Environ Microbiol. 2007;73 (10):3232-3238. doi:10.1128/aem.02579-06

30. Moriarty EM, Sinton LW, Mackenzie ML, Karki N, Wood DR. A survey of enteric bacteria and protozoans in fresh bovine faeces on New Zealand dairy farms. $J$ Appl Microbiol. 2008;105 (6):2015-2025. doi:10.1111/j.1365-2672.2008.03939.x

31. Kaper JB, Nataro JP, Mobley HL. Pathogenic Escherichia coli. Nat Rev Microbiol. 2004;2(2):123-140. doi:10.1038/nrmicro818

32. Sheng H, Wang J, Lim JY, Davitt C, Minnich SA, Hovde CJ. Internalization of Escherichia coli o157: h7 by bovine rectal epithelial cells. Front Microbiol. 2011;2:32. doi:10.3389/fmicb.2011.00032

33. Brunauer M, Roch FF, Conrady B. Prevalence of worldwide neonatal calf diarrhoea caused by bovine rotavirus in combination with Bovine Coronavirus, Escherichia coli K99 and Cryptosporidium spp.: a meta-analysis. Animals (Basel). 2021;11(4). doi:10.3390/ ani11041014

34. Svensson C, Linder A, Olsson SO. Mortality in Swedish dairy calves and replacement heifers. J Dairy Sci. 2006;89(12):4769-4777. doi:10.3168/jds.S0022-0302(06)72526-7

35. Windeyer MC, Leslie KE, Godden SM, Hodgins DC, Lissemore KD, LeBlanc SJ. Factors associated with morbidity, mortality, and growth of dairy heifer calves up to 3 months of age. Prev Vet Med. 2014;113 (2):231-240. doi:10.1016/j.prevetmed.2013.10.019

36. Acres SD, Babiuk LA. Studies on rotaviral antibody in bovine serum and lacteal secretions, using radioimmunoassay. J Am Vet Med Assoc. 1978;173(5 Pt 2):555-559.

37. Rotavirus and Coronavirus Vaccines. Vet Clin North Am Food Anim Pract. 1990;6(1):235-242. doi:10.1016/S0749-0720(15)30924-5

38. Archambault D, Morin G, Elazhary Y, Roy RS, Joncas JH. Immune response of pregnant heifers and cows to bovine rotavirus inoculation and passive protection to rotavirus infection in newborn calves fed colostral antibodies or colostral lymphocytes. Am J Vet Res. 1988;49 (7):1084-1091.

39. Castrucci G, Frigeri F, Ferrari M, et al. The efficacy of colostrum from cows vaccinated with rotavirus in protecting calves to experimentally induced rotavirus infection. Comp Immunol Microbiol Infect Dis. 1984;7(1):11-18. doi:10.1016/0147-9571(84)90011-0 


\section{Publish your work in this journal}

Veterinary Medicine: Research and Reports is an international, peerreviewed, open access journal publishing original research, case reports, editorials, reviews and commentaries on all areas of veterinary medicine. The manuscript management system is completely online and includes a very quick and fair peer-review system. Visit http://www.dovepress.com/testimonials.php to read real quotes from published authors.

Submit your manuscript here: http://www.dovepress.com/veterinary-medicine-research-and-reports-journal 